\title{
Evaluation of vaccination rooms in primary health care units
}

\author{
Avaliação das salas de vacinação de unidades de Atenção Primária à Saúde
}

Maria de Fátima Pereira de Sousa Galvão ${ }^{1}$, Paulo César de Almeida², Maria do Socorro Vieira Lopes ${ }^{3}$, Janaína Fonseca Victor Coutinho ${ }^{1}$, Mariana Cavalcante Martins ${ }^{1}$, Lorena Pinheiro Barbosa ${ }^{1}$

Objective: to evaluate the vaccination rooms of primary health care units. Methods: evaluative research, in which the Structure and Process in 89 vaccination rooms of six Regional Health Coordination Centers were evaluated through supervision of vaccine rooms of the Ministry of Health of Brazil. Results: most of the professionals were nursing technicians (76.4\%) without training in vaccination (31.5\%). In the Evaluation of General Aspects/Technical Procedures, decoration objects (43.8\%), absence of bench (22.5\%), and insufficient number of vaccines $(41.6 \%)$ were observed. In the evaluation of the Cold Chain, inadequate cleaning of refrigerators (71.9\%) and inappropriate temperatures (48.8\%) were found. Conclusion: the evaluation of vaccine rooms showed that the structure of the General Aspects/Technical Procedures and Cold Chain components presented good classification, while the evaluation of the process of these components indicated a regular classification.

Descriptors: Health Services Research; Vaccination; Immunization; Immunization Programs.

Objetivo: avaliar as salas de vacinação de unidades de Atenção Primária à Saúde. Métodos: pesquisa avaliativa, em que Estrutura e Processo foram avaliados em 89 salas de vacinas das seis Coordenadorias Regionais de Saúde, através do instrumento de supervisão das salas de vacinas do Ministério da Saúde do Brasil. Resultados: a maioria dos profissionais era técnico de enfermagem $(76,4 \%)$; sem capacitação $(31,5 \%)$. Na avaliação dos Aspectos gerais/Procedimentos técnicos, verificaram-se objetos de decoração (43,8\%), ausência de bancada $(22,5 \%)$ e quantidade insuficiente de vacinas $(41,6 \%)$. Na avaliação da Rede de Frio, constatou-se limpeza inadequada dos refrigeradores $(71,9 \%)$ e temperaturas inapropriadas $(48,8 \%)$. Conclusão: a avaliação das salas de vacinas demonstrou que a estrutura dos componentes Aspectos Gerais/Procedimentos Técnicos e Rede de Frio apresentou classificação boa, enquanto a avaliação do processo destes classificou-se como regular.

Descritores: Pesquisa sobre Serviços de Saúde; Vacinação; Imunização; Programas de Imunização.

\footnotetext{
${ }^{1}$ Universidade Federal do Ceará. Fortaleza, CE, Brazil.

${ }^{2}$ Universidade Estadual do Ceará. Fortaleza, CE, Brazil.

${ }^{3}$ Universidade Regional do Cariri. Crato, CE, Brazil.
} 


\section{Introduction}

Health evaluation is an essential tool in the planning and management of health systems and services. There is a need for surveillance to be increasingly present in daily services, which requires investments in the qualification of human resources, as well as planning, regulation, and evaluation ${ }^{(1)}$.

In Primary Health Care, vaccination services offer important indicators that have demonstrated, over time, the contribution of vaccination actions to the health sector, characterizing them as the most compensatory ones, considering their impact on the health sector. This is because of the impact on the control of immunopreventable diseases, as well as in reducing infant mortality.

In Brazil, the commitment to improve the vaccination program has been carried out through the continuous introduction of vaccines to the immunization schedule, in the development of the Immunobiological Self-Sufficiency Program and also in the strengthening of the Cold Network. Furthermore, the actions developed by the nursing team regarding management of the service, execution of vaccination activities, and management of the Cold Network contribute greatly to the development of the vaccination program in the country.

However, regarding the effectiveness of the National Immunization Program, a study demonstrates difficulties in the operationalization of the sector, including inadequate physical structure, lack of training for professionals, and failures in vaccine conservation, which can have serious consequences for the program, compromise the maintenance of vaccination coverage, or even contribute to the occurrence of outbreaks of controlled immunopreventable diseases ${ }^{(2)}$. For these reasons, the interest in knowing the working conditions of vaccine rooms through the evaluation of General Aspects/Technical Procedures and Cold Chain is increasingly frequent in the country. Therefore, the objective of this study was to evaluate the vaccination rooms of primary health care units.

\section{Methods}

Evaluative research based on the Structure-Process-Outcome triad ${ }^{(3)}$. The structure corresponds to the physical, personnel, material and financial resources, information and normative system, and technical and administrative instruments. The Process refers to activities related to the use of resources and includes the recognition of problems, diagnostic methods, and care provided. Finally, the Outcome refers to the consequences of the activities of the health services or the professionals, a dimension not addressed in this study.

The research was carried out in the city of Fortaleza, Ceará, Northeast of Brazil, considered the fourth largest metropolis in Brazil, with a population of 2,571,896 inhabitants. Data were collected from March to June 2015. The municipality is divided in six regional administrative units called Regional Coordination and each one of them has a District of Health that is responsible for the Primary Health Care units of the territory.

The municipality has 93 vaccine rooms belonging to Primary Health Care Units: Regional Coordination I - 12 rooms, Regional Coordination II - 11, Regional Coordination III - 16, Regional Coordination IV - 13, Regional Coordination V - 20 and Regional Coordination VI - 21. The study included 89 rooms that met the following inclusion criterion: being in operation in a Primary Health Care unit. The questionnaire of the Evaluation Program of the Instrument for Supervision of Vaccine Rooms of the National Immunization Program of the Ministry of Health was used to collect data $^{(4)}$.

For data analysis, the items of each component of the instrument (General Aspects, Technical Procedures and Cold Chain) were distributed in relation to structure and process. Regarding the structure, the components of General Aspects/Technical Procedures were evaluated in relation to exclusivity, accessibility, identification, walls, floor, sinks, countertops, lighting, aeration, conservation, cleaning, decoration objects, 
furniture, printed material, control cards, computers or other registration instrument, and quantity and packaging of vaccines and syringes. As for the process, the aspects evaluated were age, interval between doses, postponement, adverse events, expiration date of syringes/needles/vaccines, records, preparation and administration, hand washing, guidelines, packaging, and disposal of trash, and active search.

As for the structure of the Cold Chain, the refrigerators (operation, maintenance, conservation, thermometers, bottles, exclusive electrical outlet, circuit breaker, capacity) and thermal boxes (quantity, capacity, thermometer, coils) were evaluated. In relation to the process, we evaluated the exclusivity of the refrigerators, distance from heat, sunlight, wall and other refrigerators, drip tray, organization, warning sign not to turn off the circuit breaker in the electrical distribution box, defrost/cleaning, thermometers, temperature control map, ice coils, ambiance of the ice coils, notification of flaws, assessment form of immunobiological agents under suspicion.

The evaluation of vaccine rooms followed the model applied in Minas Gerais as methodological reference $^{(2)}$, which distributed the items of the Cold Chain according to the evaluation of structure and process. The visits to the Primary Health Care units occurred by lot and without prior appointment. The first lottery defined the order of Regional Secretariats and the second, the order of Health Units. Thus, the Regional Secretariats were visited in the following order: II, I, III, IV, V and VI. The researcher stayed in each vaccine room for one hour and thirty minutes. This time was enough to check all the points in the instrument and to make questions to the nursing professionals (assistant, technician or nurse) who were performing the vaccination actions at the time of the visit. The completion of the instrument followed the Standard Operating Procedure, developed by the authors of the research based on the regulations of the Brazilian Mi- nistry of Health.

The study evaluated 81 items. However, the present article presents the items that obtained a percentage higher than $15.0 \%$ of the response "no". A general classification was performed by averaging the scores of each vaccine room, with a variation between zero and 81 points, corresponding to the total of evaluated items $(81=100.0 \%)$. Thus, the classification of the quality of the service was made based on the scores established by the Evaluation Program of the Instrument for Supervision of Vaccine Rooms: ideal (90 to $100.0 \%$ ), good (70 to $89.0 \%$ ), regular (40 to $69.0 \%$ ), and poor (less than $40.0 \%)^{(4)}$.

The data were uploaded in the Statistical Package for the Social Sciences version 20, license \#10101131007, and analyzed by means of descriptive statistics, and absolute and relative frequencies. The binomial test was used for calculation of the Confidence Interval.

The study complied with the formal requirements set by national and international regulatory standards for research involving human beings. During the investigation, the researcher obtained the informed consent form signed by the participants of the research, according to Resolution $n-466 / 12$ of the National Health Council for research involving human beings. The study was approved by the Research Ethics Committee of the Federal University of Ceará, according to Opinion no 954,086 and Certificate of Presentation for Ethical Appraisal no 40554314,2,0000,5054.

\section{Results}

Among the nursing professionals interviewed, the majority were nursing technicians (76.4\%), with less than four years of work in the vaccination service (36.0\%), who never participated in training in the area of vaccination (31.5\%), and only one professional was working in most rooms (51.0\%) (Table 1). 
Table 1 - Distribution of nursing professionals interviewed per professional category, time working in the vaccination room, number of professionals per vaccination room, and last training $(\mathrm{n}=89)$

\begin{tabular}{lc}
\hline Variables & n (\%) \\
\hline Professional category & $3(3.4)$ \\
Nurse & $68(76.4)$ \\
Nursing technician & $18(20.2)$ \\
Nursing assistant & \\
Time working in service/years & $32(36.0)$ \\
Up to 4 & $29(32.6)$ \\
$5-10$ & $28(31.5)$ \\
$11-32$ & \\
Last training (years) & $32(36.0)$ \\
$1-4-$ & $29(32.6)$ \\
$5-14$ & $28(31.5)$ \\
Never had training & \\
Number of professionals per room & $45(50.5)$ \\
1 & $44(49.5)$ \\
\hline
\end{tabular}

Table 2 presents the items of Structure and Process regarding General Aspects/Technical Procedures. The average of the items related to the Structure reached a percentage of $71.4 \%$, classified as good. Regarding the items related to the Process, an average percentage of $58.4 \%$ was obtained, classified as regular.

Regarding the Structure and Process of the Cold Room of the vaccine rooms, Table 3 shows that the evaluation of the items referring to the Structure reached an average percentage of $80.7 \%$, classifying it as good, while the Process obtained an average percentage of $65.9 \%$, being classified as regular.

Table 2 - Distribution of Structure and Process items regarding General Aspects/Technical Procedures of vaccination rooms of Primary Health Care units ( $n=89)$

\begin{tabular}{|c|c|c|c|c|}
\hline \multirow{2}{*}{ Variables } & \multicolumn{2}{|c|}{ Yes } & \multicolumn{2}{|c|}{ No } \\
\hline & n (\%) & ${ }^{*} \mathbf{C I}_{95 \%}$ & n (\%) & $\mathbf{C I}_{95 \%}$ \\
\hline \multicolumn{5}{|l|}{ Structure } \\
\hline Exclusivity & $74(83.1)$ & $0.73-0.90$ & $15(16.9)$ & $0.09-0.26$ \\
\hline Waterproof floor and easily cleansed & $73(82.0)$ & $0.72-0.89$ & $16(18.0)$ & $0.10-0.27$ \\
\hline Countertops easily cleansed & $69(77.5)$ & $0.67-0.85$ & $20(22.5)$ & $0.14-0.32$ \\
\hline Ideal storage conditions & $68(76.4)$ & $0.66-0.84$ & $21(23.6)$ & $0.15-0.33$ \\
\hline General cleaning done every 15 days & $44(49.4)$ & $0.38-0.60$ & $45(50.6)$ & $0.39-0.61$ \\
\hline Absence of decorating objects & $50(56.2)$ & $0.45-0.66$ & $39(43.8)$ & $0.33-0.54$ \\
\hline Control card for children & $4(4.5)$ & $0.01-0.11$ & $85(95.5)$ & $0.88-0.98$ \\
\hline Control card for adults & $3(3.4)$ & $0.00-0.09$ & $86(96.6)$ & $0.90-0.99$ \\
\hline Cards organized according to return date & $3(3.4)$ & $0.00-0.95$ & $86(96.6)$ & $0.90-0.99$ \\
\hline Computer or log book & $65(73.0)$ & $0.62-0.81$ & $24(27.0)$ & $0.18-0.37$ \\
\hline Syringes/needles properly packed & $74(83.1)$ & $0.73-0.90$ & $15(16.9)$ & $0.09-0.26$ \\
\hline Sufficient amount of vaccinations & $52(58.4)$ & $0.47-0.68$ & $37(41.6)$ & $0.31-0.52$ \\
\hline Sufficient syringes/needles & $37(41.6)$ & $0.47-0.68$ & $52(58.4)$ & $0.31-0.52$ \\
\hline Total $(\%)$ & $(71.4)$ & & $(28.6)$ & \\
\hline \multicolumn{5}{|l|}{ Process } \\
\hline Observes situations of postponement of the vaccine & $30(33.7)$ & $0.24-0.44$ & $59(66.3)$ & $0.55-0.75$ \\
\hline Investigates the occurrence of adverse events & $17(19.1)$ & $0.11-0.28$ & $72(80.9)$ & $0.71-0.88$ \\
\hline Observes the shelf-life of the vaccine after it is opened & $30(33.7)$ & $0.24-0.44$ & $59(66.3)$ & $0.55-0.75$ \\
\hline Records date and time of bottle opening & $25(28.1)$ & $0.19-0.38$ & $64(71.9)$ & $0.61-0.80$ \\
\hline Uses correct technique for administration & $68(76.4)$ & $0.66-0.84$ & $21(23.6)$ & $0.15-0.33$ \\
\hline Performs hand washing before/after care & $36(40.4)$ & $0.30-0.51$ & $53(59.6)$ & $0.48-0.69$ \\
\hline Guides the user about the vaccine administered & $70(78.7)$ & $0.68-0.86$ & $19(21.3)$ & $0.13-0.31$ \\
\hline Sorts garbage types into different packages & $34(38.2)$ & $0.28-0.49$ & $55(61.8)$ & $0.50-0.71$ \\
\hline Inactivates vaccines with live micro-organisms & $11(12.4)$ & $0.06-0.21$ & $78(87.6)$ & $0.78-0.93$ \\
\hline Performs active search with the clientele & - & & $89(100.0)$ & \\
\hline Performs active search for missing patients & - & & $89(100.0)$ & \\
\hline Total (\%) & $(58.4)$ & & $(41.6)$ & \\
\hline
\end{tabular}


Table 3 - Distribution of items related to the Structure and Process of the Cold Chain of the vaccination rooms in Primary Health Care units

\begin{tabular}{|c|c|c|c|c|}
\hline \multirow{2}{*}{ Variables } & \multicolumn{2}{|c|}{ Yes } & \multicolumn{2}{|c|}{ No } \\
\hline & n (\%) & ${ }^{*} \mathbf{C I}_{95 \%}$ & n (\%) & $\mathrm{CI}_{95 \%}$ \\
\hline \multicolumn{5}{|l|}{ Structure } \\
\hline Refrigerators with ideal state of conservation & $99(83.1)$ & $0.75-0.89$ & $20(16.9)$ & $0.10-0.24$ \\
\hline Preventive/corrective maintenance service & - & & $119(100.0)$ & \\
\hline Exclusive electric outlet & $99(83.1)$ & $0.75-0.89$ & $20(16.9)$ & $0.10-0.24$ \\
\hline Specific circuit breaker & $99(83.1)$ & $0.75-0.89$ & $20(16.9)$ & $0.10-0.24$ \\
\hline Thermometer available & $120(35.8)$ & $0.30-0.41$ & $215(64.2)$ & $0.58-0.69$ \\
\hline Total (\%) & $(80.7)$ & & (19.2) & \\
\hline \multicolumn{5}{|l|}{ Process } \\
\hline Refrigerator $20 \mathrm{~cm}$ away from the wall and from other refrigerators & $52(43.6)$ & $0.34-0.53$ & $67(56.4)$ & 0.46-0.65 \\
\hline Maintains the drip tray & $85(71.4)$ & $0.62-0.79$ & $34(28.6)$ & $0.20-0.37$ \\
\hline 1st shelf: oral polio, triviral and yellow fever & $34(28.5)$ & $0.20-0.37$ & $85(71.5)$ & $0.62-0.79$ \\
\hline Keep warning not to turn off the circuit breaker & $7(7.9)$ & $0.03-0.15$ & $82(92.1)$ & $0.84-0.96$ \\
\hline Ideal refrigerator cleaning & $101(84.4)$ & $0.77-0.90$ & $18(15.6)$ & $0.09-0.22$ \\
\hline Cleaning every 15 days or ice sheet $0.5 \mathrm{~cm}$ & $69(77.5)$ & $0.67-0.85$ & $20(22.5)$ & $0.14-0.32$ \\
\hline Defrost/cleaning properly described & $25(28.1)$ & $0.19-0.38$ & 64(71.9) & $0.61-0.80$ \\
\hline Records refrigerator temperature: start and end of day & $98(82.3)$ & $0.74-0.88$ & $21(17.7)$ & $0.11-0.25$ \\
\hline Appropriate temperatures recorded & $61(51.2)$ & $0.41-0.60$ & $58(48.8)$ & $0.39-0.58$ \\
\hline Monitors temperature of the thermal boxes & $14(15.7)$ & $0.08-0.24$ & $75(84.3)$ & $0.75-0.91$ \\
\hline Ambiance of coils before placing them in the thermal boxes & $57(64.0)$ & $0.53-0.73$ & $32(36.0)$ & $0.26-0.46$ \\
\hline Properly described coil ambiance & $27(30.3)$ & $0.21-0.40$ & $62(69.7)$ & $0.59-0.78$ \\
\hline Instantly notifies failures to top instance & $58(65.2)$ & $0.54-0.74$ & $31(34.8)$ & $0.25-0.45$ \\
\hline Fill in the evaluation form about immunobiological agents under suspicion & $17(19.1)$ & $0.11-0.28$ & $72(80.9)$ & $0.71-0.88$ \\
\hline Vaccines under suspicion maintained at $+2^{\circ} \mathrm{C}$ to $+8^{\circ} \mathrm{C}$ & $20(22.5)$ & $0.14-0.32$ & $69(77.5)$ & $0.67-0.85$ \\
\hline Total (\%) & $(65.9)$ & & $(34.1)$ & \\
\hline
\end{tabular}

\section{Discussion}

The study presented some limitations. The first one was the use of the data collection instrument of the Brazilian Ministry of Health, whose last update occurred in 2004, when the new recommendations for the functioning of vaccine rooms published in 2014 by the Ministry of Health had not been incorporated by the Ministry itself. The second one consisted of interviewing and making observations only with the professional who was in service at the moment of the visit by the researcher.

The nurse plays the role of technically responsible professional for the immunization service, being responsible for the coordination of vaccine rooms, service management, control and execution of vaccinations, and management of the Cold Chain in Brazilian municipalities, a fact reported in national studies ${ }^{(2,5-7)}$.
However, there was a low proportion of nurses working exclusively in the vaccination rooms because, in most cases, they divided the workload with activities other than immunization. In half of the rooms evaluated there was only one professional, a situation that has been observed in other places in the country ${ }^{(5)}$ and is contrary to the recommendation of the National Immunization Program, which suggest that there must be at least two professionals ${ }^{(8)}$. This shortage of personnel can have repercussions on service provision, due to the many tasks that the professionals have to carry out, the high number of immunobiological agents in the routine scheme, and the reduced number of trained employees ${ }^{(6)}$.

We highlight the high number of workers who had never performed training, corroborating a study 
carried out in Terezina, Piauí, Brazil ${ }^{(7)}$. There is a need for greater attention to this aspect because training the professionals to solve problems of the sector and manage the Cold Chain promotes the quality of the service provided ${ }^{(2)}$.

Regarding the evaluation of the General Aspects/Technical Procedures related to the Structure of the vaccination rooms, there were some flaws that compromise the structure: infiltrations in the walls and ceiling, lack of bench for the preparation of vaccines, including vaccination rooms which had undergone recent reform. As for cleanliness, the noncompliance in the frequency of realization of this task and the use of decoration objects (paintings on the walls, pots of artificial plants and sacred images) compromise the hygiene of the sector.

According to the interviewees, the quantity of vaccines and syringes/needles was insufficient to meet the monthly demand. The shortage of vaccines causes a missed opportunity for vaccination, which may lead to discrediting of the service in the opinion of users, impairing vaccination coverage and jeopardizing the control of immunopreventable diseases. In a rapid monitoring of vaccination coverage in Brazil in $2012,27.5 \%$ of the interviewees claimed that the lack of vaccinations in the unit was a reason for non-vaccination, which constitutes a threat to the control of immunopreventable diseases which are controlled/ eliminated in the country, a situation that needs to be corrected $^{(9)}$.

Regarding the General/Technical Procedures Process, with respect to the activities that preceded the administration of vaccines, little attention was paid to situations of postponement and investigation of adverse events, exposing the vaccinated people to the risk of severe adverse reactions, or even associate the vaccine with an event unrelated to it.

Regarding the technique used to administer vaccines, the percentage of inadequacy was due to: inappropriate distance between two administrations in the same limb, control outside the recommended muscle area (above or below) in the deltoid region and/or the vasodilateral region of the thigh and lack of aspiration in the administrations by intramuscular route. It is important to consider that these errors also predispose to the risk of adverse events, such as fever and local events ${ }^{(10)}$. With regard to hand washing, low adherence of the evaluated professionals was observed. The study pointed out as motivators of hand washing: interest in the work, the possibility to give an opinion on the acquisition of hand hygiene products, flexibility in prioritizing caregiving actions, and autonomy in the execution ${ }^{(11)}$.

Regarding the guidelines provided at the moment of vaccination, which were considered insufficient in the study, it is important to consider that they may reflect on the correct compliance or non-compliance of the family vaccination schedule, since the provision of clear information by professionals to users is an important strategy for adherence to vaccination ${ }^{(12)}$.

Regarding the disposal of garbage, it was found that some rooms did not use boxes for specific collection of sharp-cutting material, and, according to the interviewees' reports, they were unavailable due to a shortage in the municipality. It should be noted that garbage resulting from vaccination activities in the city of Fortaleza, Ceará, Brazil, is collected by a company destined for this purpose, and it has therefore an appropriate final destination.

Among the evaluated items about the Structure of the Cold Chain, it was verified that the refrigerators presented problems in the conservation status. The absence of preventive/corrective maintenance was stressed by the interviewees and contradicts the recommendation of the National Immunization Program on periodic, predictive and preventive maintenance aimed at guaranteeing the safety, performance and functionality of the equipment, extending the useful life and ensuring the conservation of immunobiological products ${ }^{(13)}$.

The refrigeration equipment used in the vaccination rooms of Fortaleza, Ceará, Brazil were: thermal boxes and domestic frost free refrigerators of the common type, which is not in line with the instruction to 
replace them by refrigerated chambers ${ }^{(8,13)}$.

Regarding the Process of the Cold Chain, it was found that the vaccines inadequately arranged on the first shelf were mainly: BCG, antitetanic and influenza. It is noteworthy that some refrigerators had only two shelves, following a recommendation of the National Immunization Program ${ }^{(8)}$, but they were overloaded, and were insufficient for adequate organization of the vaccines.

The correct organization of the domestic refrigerator and its hygienization allow the maintenance of adequate temperatures in all spaces. The hygienization showed flaws due to the products used (equipment was cleaned with sodium hypochlorite and/or alcohol and/or were simply dried), when it should be cleaned with neutral soap, the only product recommended for the procedure ${ }^{(8)}$. This situation was aggravated by the lack of knowledge about the need to clean frost free equipment.

Maps of temperature records of the refrigerators indicated temperatures below $+2^{\circ} \mathrm{C}$ or above $+8^{\circ} \mathrm{C}$. An international study found a high frequency of non-standard temperature recording and found that, in developed countries, exposure to freezing temperatures is more frequent, whereas in developing countries exposure to overheating is more frequent ${ }^{(14)}$. It should be emphasized that the daily temperature control map should be considered an important instrument in the service because it offers information on the temperature variation of the refrigerator, being a document that validates the quality of the refrigeration of the vaccines ${ }^{(2)}$.

A minimum number of thermal boxes had thermometers for temperature monitoring. However, it is known that low temperatures affect vaccines more than the highest, and that freezing in the thermal boxes can occur mainly in the first two hours of use $^{(15-16)}$. The results of this study indicate the need to the service management to implement corrective actions and of professionals who apply them. They also showed the need for effective evaluation processes as a continuous tool to support management, aiming at quality service. Furthermore, the findings presented may support the creation of strategies for continuing education for professionals working in the vaccination service.

\section{Conclusion}

The evaluation of vaccine rooms showed that the structure of the General Aspects/Technical Procedures and the Cold Chain components presented good classification, while the evaluation of the process of these components indicated a regular classification.

\section{Acknowledgements}

To the Conselho Nacional de Desenvolvimento Científico e Tecnológico, for the research productivity grant provided under no 305493/2015-9.

\section{Collaborations}

Galvão MFPS participated in the project design, and in the analysis and interpretation of the data. Almeida PC contributed in the analysis and interpretation of the data. Lopes MSV, Coutinho JFV, Martins MC and Barbosa LP collaborated in the writing of the article, critical review of the relevant intellectual content, and approval of the final version to be published.

\section{References}

1. Carvalho ALB, Shimizu HE. A institucionalização das práticas de monitoramento e avaliação: desafios e perspectivas na visão dos gestores estaduais do Sistema Único de Saúde (SUS). Interface. 2017; 21(60):23-33. doi: https://dx.doi. org/10.1590/1807-57622015.0817

2. Oliveira VC, Gallardo MDPS, Alcêncio RA, Gontijo TL, Pinto IC. Avaliação da qualidade de conservação de vacinas na atenção primária à saúde. Ciênc Saúde Coletiva. 2014; 19(9):388998.doi:http://dx.doi.org/10.1590/141381232014199.12252013 
3. Donabedian A. Criteria, norms and standarts of quality: what do they mean. Am J Public Health [Internet]. 1981 [cited Nov 13, 2018]; 71(4):409-12. Available from: https://www.ncbi. nlm.nih.gov/pmc/articles/PMC1619670/pdf/ amjph00664-0059.pdf

4. Ministério da Saúde (BR). Programa de Avaliação do Instrumento de Supervisão Salas de Vacina: manual do usuário [Internet]. 2003 [citado 2018 nov 13]. Disponível em: www.pni.datasus.gov.br/ Download/Paissv/PAISSV-Instrumento.doc

5. Almeida MG, Araújo TME, Nunes BMVT, Moura MEB, Martins MCC. Knowledge and professional practice on conservation of vaccines. J Res Fundam Care Online. 2014; 6(suppl):10-21. doi: http:// dx.doi.org/10.9789/2175-5361.2014.v6i5.10-21

6. Brito MFP, Gerin L, Couto ECA, Cunha IS, Corsini MCMM, Gonçalves MC. Caracterização das notificações de procedimentos inadequados na administração de imunobiológicos em Ribeirão Preto, São Paulo, 2007-2012. Epidemiol Serv Saúde. 2014; 23(1):33-44. doi: http://dx.doi. org/10.5123/51679-49742014000100004

7. Deus SEM, Marques ADB, Teixeira JCL, Deis PRM, Moraes MEA, Macedo DF. Study of the procedures for conservation of vaccines of the National Immunization Program. Rev Enferm UFPE on line [Internet]. 2016 [cited Nov 13, 2018]; 10(3):1038-46. Available from: https://periodicos.ufpe.br/revistas/revistaenfermagem/article/ viewFile/11056/12472

8. Ministério da Saúde (BR). Manual de Normas e Procedimentos para Vacinação [Internet]. 2014 [citado 2018 nov 13]. Disponível em: http:// portalsaude.saude.gov.br/images/pdf/2014/ dezembro/11/Manual-procedimentosvacinacao-web.pdf

9. Domingues CMAS, Teixeira AMS. Coberturas vacinais e doenças imunopreveníveis no Brasil no período 1982-2012: avanços e desafios do Programa Nacional de Imunizações. Epidemiol Serv Saúde. 2013; 22(1):9-27. doi: http://dx.doi. org/10.5123/S1679-49742013000100002
10. Ministério da Saúde (BR). Manual de vigilância epidemiológica de eventos adversos pósvacinação [Internet]. 2013 [citado 2018 nov 13]. Disponível em: www.saude.pr.gov.br/arquivos/ File/-01VACINA/manual_Eventos_adversos.pdf

11. Giordani AT, Sonobre HM, Ezaias GM, Valério MA, Andrade D. The nursing team's compliance with hand hygiene: motivational factors. Rev Rene. 2014; 15(4):559-68. doi: http://dx.doi. org/10.15253/2175-6783.2014000400002

12. Ventola CL. Immunization in the United States: recommendations, barriers, measures to improve compliance. Pharm Ther [Internet]. 2016 [cited Nov 13, 2018]; 41(7):426-36. Available from: https://www.ncbi.nlm.nih.gov/pmc/articles/ PMC4927017/

13. Ministério da Saúde (BR). Manual de rede de frio [Internet]. 2013 [citado 2018 nov 13]. Disponível em: www.bvsms.saude.gov.br/bvs/plublicações/ manual_rede_frio4ed.pdf

14. Yakun MN, Ateudjieu J, Pélagie FR, Walter EA, Watcho P. Factors associated with the exposure of vaccines to adverse temperature conditions: the case of North West region, Cameroon. BMC Res Notes. 2015; 8:277-83. doi: http://dx.doi. org/10.1186/s13104-015-1257-y

15. Departmente of Health and Ageing (AU). National vaccines storage guidelines - strive for 5 . Canberra: Imumunise Australia Program [Internet]. 2013 [cited Nov 13, 2018]. Available from: http://www. immunise.health.gov.au/internet/immunise/ publishing.nsf/content/Available from: cnt

16. Tuells J. Visibilidad de la cadena de frío vacunal em España. An Sist Sanit Navar. 2013; 2(36):309-20. doi: dx.doi.org/10.4321/S113766272013000200014 